\title{
Potential Oxygen-Carrying Complexes by Design
}

\author{
Víctor M. Rosas-García, Perla Elizondo Martínez*, Nancy Pérez Rodríguez, Blanca Nájera Martínez \\ Universidad Autónoma de Nuevo León UANL, Facultad de Ciencias Químicas, Ave Universidad S/N, Cd. Universitaria, San Nicolás de \\ los Garza, N. L., México, C.P. 66450 \\ *E-mail:perla.elizondomr@uanl.edu.mx
}

Recibido 30 de agosto de 2012, Aceptado 26 de septiembre de 2012

\begin{abstract}
There are twenty four elements known to be necessary for human life, seven of which are transition metals. These seven elements; V, Cr, Mn, Fe, Co, Cu, and $\mathrm{Zn}$ have an important role in living systems due to their ability to form complexes with diverse donor groups present in biological systems. [Co(salen)] has been previously studied as a model compound for oxygen transport. In this work other metallic complexes, Ni(II), $\mathrm{Zn}(\mathrm{II}), \mathrm{Cu}(\mathrm{II})$ and $\mathrm{Fe}(\mathrm{II})$ with N,N'bis(salicylaldehyde)ethylenediamine (salen- $\mathrm{H}_{2}$ ) were synthesized. The active form of each complex was obtained by reaction with dimethylsulfoxide. The ability of these metallic complexes to act as $\mathrm{O}_{2}$ carriers was determined. From the results, the complexes of the $\mathrm{Co}(\mathrm{II}), \mathrm{Fe}(\mathrm{II})$ and $\mathrm{Cu}$ (II) with salen are able to transport oxygen with an ordering of $\mathrm{Co}(\mathrm{II})>$ $\mathrm{Fe}(\mathrm{II})>\mathrm{Cu}$ (II) regarding the capacity to carry $\mathrm{O}_{2}$. We used the PM7 semiempirical hamiltonian to study the complexes of salen with $\mathrm{Co}(\mathrm{II}), \mathrm{Cu}(\mathrm{II}), \mathrm{Fe}(\mathrm{II})$ and $\mathrm{Ni}(\mathrm{II})$ and their potential as oxygen carriers. We performed full geometry optimizations in the gas phase for each complex, its active form with DMSO as ligand, and with dioxygen complexed with the active form. We discuss energetic features associated with the binding of dioxygen to the complexes.
\end{abstract}

\section{Introduction}

Transport and storage of molecular oxygen is an essential physiological function carried out by molecular species containing $\mathrm{Fe}(\mathrm{II})$ and $\mathrm{Cu}(\mathrm{II})$ which are found in blood and can have a variety of functions in the blood system. An important example is the hemoglobin which contains the porphyrin-Fe complex. This complex coordinates an oxygen molecule, forming the oxyhemoglobin, which is responsible for the red color of blood [1, 2]. Other porphyrin-metal complexes function as oxygen stores, such as myoglobin, the nonporphyrin metalloproteins hemerytrin and hemocyanin. The last two can store 2 moles of oxygen per mole of complex.

In hemoglobin there are four flat units of porphyrin, which are referred to as heme groups. Each heme group contains four nitrogen atoms coordinated with a $\mathrm{Fe}(\mathrm{II})$ cation in a square flat arrangement. Figure 1 shows a scheme of a heme group where iron is coordinated to the four nitrogen atoms from the porphyrin; it is additionally coordinated to one nitrogen belonging to a histidine from the surrounding protein (not shown) and the sixth position holding one oxygen molecule [3, 4], this bond is possible because an oxygen atom donates one of its electron pairs to the iron $[5,6]$.

This reaction can be reversible

$$
\text { Carrier }+\mathrm{O}_{2} \rightleftarrows \text { Carrier }\left(\mathrm{O}_{2}\right)
$$

Equilibrium is displaced to the right when the free heme sites from hemoglobin encounter a high concentration of oxygen due to a high partial pressure of oxygen in the lungs. Equilibrium is displaced to the left when the oxyhemoglobin reaches a cell in which the partial pressure of oxygen is low, setting it free in the tissues as required for cellular metabolism $[7,8]$.
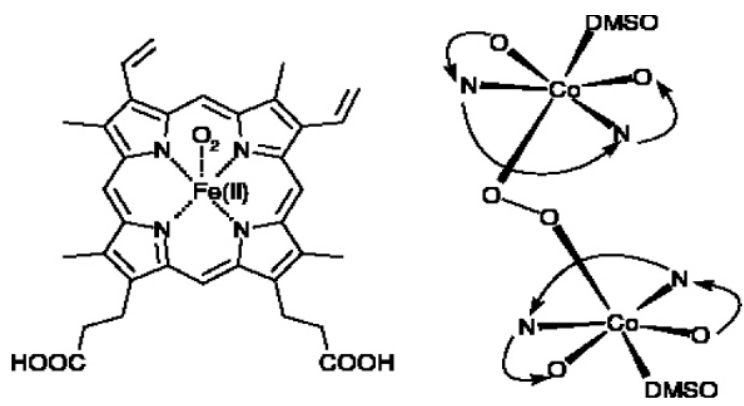

Figure 1. On the left, structure of basic backbone of a porphyrin, known as Heme b $\mathrm{B}$, with $\mathrm{O}_{2}$ coordinated to the iron. On the right: model compound in which the metallic ion $\mathrm{Co}(\mathrm{II})$ is coordinated with two nitrogen atoms and two oxygen atoms that belong to the ligand. The fifth position around the metallic ion is occupied by the oxygen atom from the DMSO, and its sixth position will be occupied by a bridging dioxygen molecule.

Seven out of the twenty four elements that are known to be necessary for human life are first row transition metals. These seven elements $\mathrm{V}, \mathrm{Cr}, \mathrm{Mn}$, 
$\mathrm{Fe}, \mathrm{Co}, \mathrm{Cu}$, and $\mathrm{Zn}$ have an important role in live systems due to their ability to form complexes with diverse donor groups present in biological systems $[9,13] .[\mathrm{Co}($ salen$)]$ is a species that has been studied previously as a model for oxygen transport [14-16] (see figure 1 for a schematic depiction). The metallic ion Co(II) is coordinated with two nitrogen atoms and two oxygen atoms that belong to the ligand. The fifth position around the metallic ion is occupied by the oxygen atom from the DMSO and its sixth position is occupied by a briding dioxygen molecule.

In this work, other metallic complexes derived from salen were synthesized to be studied as model compounds of biological systems. The potential of these metallic complexes as $\mathrm{O}_{2}$ carriers was determined and compared to Fe-porphyrin.

\section{Experimental}

All the substances used were Aldrich Chemical Co. analytical grade.

\subsection{Synthesis of Salen [9]}

Ethanol (34.1 $\mathrm{ml})$ was added to 2hydroxybenzaldehyde $(3.5 \mathrm{ml})$, then ethylendiamine $(2.2 \mathrm{ml})$ was added slowly to the warm mixture. The compound formed was filtered off, and washed with ethanol. The yellow solid obtained was recrystallised from ethanol. Yield $64.3 \%$; IR $(\mathrm{KBr}$ disc) $3440 \mathrm{~cm}^{-1}(\mathrm{O}-\mathrm{H}), 1636 \mathrm{~cm}^{-1}(\mathrm{C}=\mathrm{N})$; UV-Vis $\lambda_{\max } 332 \mathrm{~nm}$.

\subsection{Synthesis of the Complexes}

\section{Scheme I}
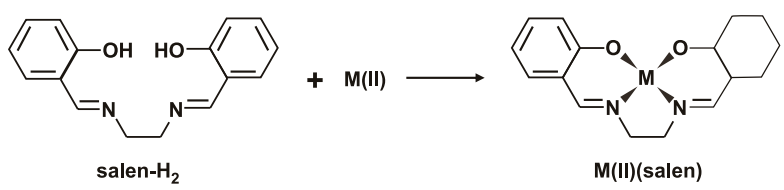

M(II)(salen)

To a refluxing solution of salen- $\mathrm{H}_{2}$ in ethanol, was slowly added an aqueous solution of corresponding metal acetate according to the desired complex. The reflux was maintained for one hour under an inert atmosphere at $80-90{ }^{\circ} \mathrm{C}$. The solid products obtained were filtered off, washed, and purified with an adequate solvent. Yields $=61.2-88 \%$; IR ( $\mathrm{KBr}$ disc) $1625-1635 \mathrm{~cm}^{-1}(\mathrm{C}=\mathrm{N})$; to see UV-Vis $\lambda_{\max }$ for each complex refer to Table 1 .

\subsection{Synthesis of the Active Form of the Complexes}

\section{Scheme II}

$2\left[\mathrm{M}^{2+}\right.$ (salen) $]+2 \mathrm{DMSO}+\mathrm{O}_{2} \rightleftarrows$ $\left[(\text { DMSO }) \mathrm{M}^{2+}(\text { salen })\right]_{2} \mathrm{O}_{2}$

The reaction depicted in Scheme II, using the apparatus depicted in Figure 2, was performed as follows: $0.05 \mathrm{~g}$ of the complex $\mathrm{M}$ (salen) $\left(\mathrm{M}=\mathrm{Co}^{2+}\right.$, $\left.\mathrm{Cu}^{2+}, \mathrm{Zn}^{2+}, \mathrm{Ni}^{2+}, \mathrm{Fe}^{2+}\right)$ was placed in the test tube 1 . Then $5 \mathrm{ml}$ of DMSO were introduced into test tube 2. Water was added to addition funnel 4 and the stopcock opened to allow levelling of the water between pipette 3 and addition funnel 4 .

The DMSO was spilled over the complex and shaken for fifteen minutes. The displaced water volume was read in the pipette at STP, and the transported moles of oxygen were calculated using equation (1):

$$
n=(P-f) V /(R T)
$$

where $n$ is number of moles of oxygen, $P$ is pressure (in $\mathrm{mmHg}$ ), $f$ is the pressure difference before and after adding the DMSO to the complex, as read from the burette, $V$ is volume, $R$ is the gas constant and $T$ is the temperature. To test for the reversibility of the oxygen absorption, a few drops of chloroform were added to the formed product, to check for the release of oxygen.

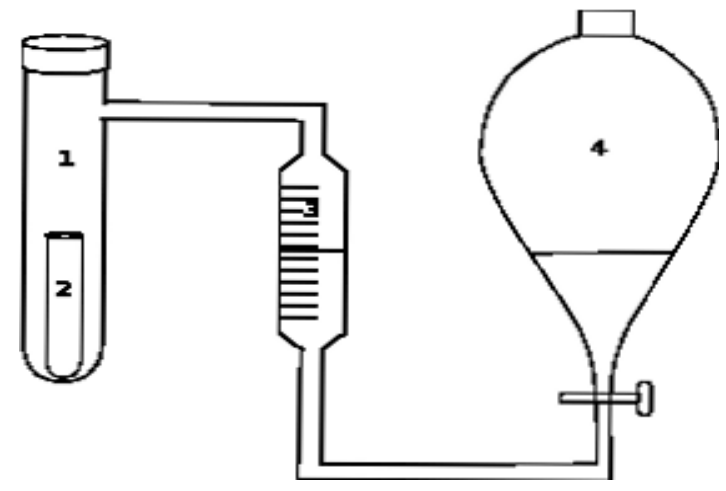

Figure 2. Apparatus for preparation of active form of $\mathrm{M}($ salen$)$ and its dioxygen uptake.

\subsection{Computational studies}

All the complexes and the salen structures were built and optimized using MOPAC2012 [17]. The 
PM7 [17] Hamiltonian was used in all calculations. After optimization, vibrational analyses of all the stationary points obtained were calculated to identify and keep only true energetic minima.

\section{Results and discussion}

A series of metal complexes of salen having 1:1 (Metal:Ligand) stoichiometries have been isolated from alcohol solutions in good yield and data concerning their characterization are summarized in Table 1 .

The experimental IR spectra of the complexes show imine stretch frequencies in the region 1625$1635 \mathrm{~cm}^{-1}$, which are split and/or shifted relative to that of the corresponding free ligand $\left(1636 \mathrm{~cm}^{-1}\right)$ due to complexation. In the individual spectra the absence of a band attributable to the O-H stretching vibration (3440 $\mathrm{cm}^{-1}$ in salen) was also evident, suggesting that the metal ions were also bound to the oxygen atoms of the hydroxyl groups. The computational results are qualitatively consistent with the shift of the $\mathrm{C}=\mathrm{N}$ band when going from free salen to the complex, although the shift is overestimated.

Table 1. IR and UV-VIS spectral data for the ligand and complexes. The computational results were obtained from the M(salen) complex.

\begin{tabular}{|c|c|c|c|}
\hline Compound & $\lambda_{\max .}(\mathrm{nm})$ & $\begin{array}{c}\mathrm{C}=\mathrm{N} \vee \mathrm{cm}^{-1} \\
(\text { exp.) }\end{array}$ & $\begin{array}{c}v_{\text {cm }}^{-1} \\
\text { (by PM7) }\end{array}$ \\
\hline Salen- $\mathrm{H}_{2}$ & 332 & 1636 & 1837,1853 \\
\hline $\mathrm{Fe}^{\mathrm{II}}$ (salen) & 487 & 1625 & 1691,1698 \\
\hline $\mathrm{Co}^{\mathrm{II}}$ (salen) & 492 & 1630 & 1665,1695 \\
\hline $\mathrm{Ni}^{\mathrm{II}}$ (salen) & 420 & 1630 & $1438 *$ \\
\hline $\mathrm{Cu}^{\mathrm{II}}$ (salen) & 430 & 1635 & 1733,1765 \\
\hline $\mathrm{Zn}^{\mathrm{II}}$ (salen) & 317 & 1632 & 1776,1789 \\
\hline
\end{tabular}

Table 2 shows that the complexes of $\mathrm{Co}(\mathrm{II}), \mathrm{Fe}(\mathrm{II})$ and $\mathrm{Cu}$ (II) with salen in its active form are able to transport oxygen. In these model systems the oxygen molecule may be as $\mathrm{O}_{2}{ }^{-}$or $\mathrm{O}_{2}{ }^{2-}$. $\mathrm{Ni}(\mathrm{II})$ and $\mathrm{Zn}(\mathrm{II})$ complexes are unable to absorb oxygen so they are not active.

From the results the complexes of the $\mathrm{Co}(\mathrm{II})$, $\mathrm{Fe}(\mathrm{II})$ and $\mathrm{Cu}(\mathrm{II})$ with Salen are able to transport oxygen. The order of capacity to carry $\mathrm{O}_{2}$ for the complexes studied here is $\mathrm{Co}(\mathrm{II})>\mathrm{Fe}$ (II) $>\mathrm{Cu}$ (II).

The salen complex of Co is very well known experimentally as a dioxygen transporter [18]. The PM7 results for the complexes (see Table 3) agree qualitatively with the experimental findings. First of all, PM7 predicts that DMSO does not bind to the
Table 2. Metallic complexes with $N, N^{\prime}$ bis(salicylaldehyde)ethylenediamine (salen) and their ability to carry oxygen.

\begin{tabular}{|c|c|c|c|c|}
\hline \multirow{2}{*}{ Complexes } & \multirow{2}{*}{$\begin{array}{c}\text { Yield } \\
(\%)\end{array}$} & \multicolumn{2}{|c|}{ Color } & \multirow{2}{*}{$\begin{array}{c}\text { Moles of } \\
\mathrm{O}_{2} / \text { mole } \\
\text { of } \\
\text { complex }\end{array}$} \\
\hline & & $\begin{array}{c}\text { Inactive } \\
\text { Form }\end{array}$ & $\begin{array}{c}\text { Active } \\
\text { Form }\end{array}$ & \\
\hline $\mathrm{Fe}^{\mathrm{II}}$ (salen) & 84.7 & Red-brown & Wine red & 0.313 \\
\hline $\mathrm{Co}^{\mathrm{II}}$ (salen) & 61.2 & Purple & Brown & 1.132 \\
\hline $\mathrm{Ni}^{\mathrm{II}}$ (salen) & 83.7 & Orange & - & - \\
\hline $\mathrm{Cu}^{\mathrm{II}}$ (salen) & 88.0 & Green & Blue & 0.272 \\
\hline $\mathrm{Zn}^{\mathrm{II}}$ (salen) & 82.7 & Pale yellow & - & - \\
\hline
\end{tabular}

$\mathrm{Ni}($ salen) nor the $\mathrm{Zn}($ salen) complexes, thus preventing the formation of the activated complex. The dioxygenated $\mathrm{Cu}$ complex could not be calculated, because of repeated failures to achieve self-consistent field, but the relative energies found for $\mathrm{Fe}$ and $\mathrm{Co}$ are in qualitative agreement with the experimental finding that $\mathrm{Co}$ is a better oxygen carrier than $\mathrm{Fe}$ as the dioxygenated complex is more stable, but stability is not clearly related to capacity.

Table 3. PM7 energies of the salen complexes, their active form with DMSO and the active form before and after binding dioxygen. Relative energies in $\mathrm{kcal} /$ mole are in parentheses. Where appropriate, we have included the values of the $\mathrm{S}^{2}$ operator. PM7 energy of dioxygen: $25.67333 \mathrm{kcal} / \mathrm{mole}$.

\begin{tabular}{|c|c|c|c|c|}
\hline \multirow[b]{2}{*}{$\begin{array}{l}\text { Metal } \\
\text { (M) }\end{array}$} & \multicolumn{4}{|c|}{$\begin{array}{l}\text { PM7 energies } \\
\text { (kcal/mol) }\end{array}$} \\
\hline & M(salen) & $\begin{array}{l}\text { M(salen) } \\
\text { (DMSO) }\end{array}$ & $\begin{array}{c}\text { M(salen) } \\
\text { (DMSO)(O) }\left(\mathrm{O}_{2}\right)\end{array}$ & $\begin{array}{c}\mathrm{M}(\text { salen) } \\
\text { (DMSO)(O) } \\
\text { relative } \\
\text { energy* }\end{array}$ \\
\hline $\mathrm{Fe}$ & -20.42729 & -94.9073 & -117.79307 & 27.3729 \\
\hline Co & 70.59573 & -3.88354 & -41.86107 & -139.58286 \\
\hline $\mathrm{Ni}$ & 62.48193 & $\begin{array}{l}\text { Does not } \\
\text { form }\end{array}$ & --- & --- \\
\hline $\mathrm{Cu}$ & 69.61649 & -43.10015 & $\begin{array}{c}\text { Not } \\
\text { converged }\end{array}$ & --- \\
\hline $\mathrm{Zn}$ & -19.79771 & $\begin{array}{l}\text { Does not } \\
\text { form }\end{array}$ & --- & --- \\
\hline
\end{tabular}

$*$ considering $\mathrm{M}($ salen $)(\mathrm{DMSO})+\mathrm{O}_{2}$ as reagents.

\section{Conclusions}

We have shown that salen reacts with $\mathrm{Fe}, \mathrm{Co}, \mathrm{Ni}$ and $\mathrm{Cu}$ to form the corresponding complex. For the complexes studied here, only $\mathrm{Co}(\mathrm{II}), \mathrm{Fe}(\mathrm{II})$ and $\mathrm{Cu}$ (II) formed complexes able to transport oxygen. The ordering with respect to the capacity to carry $\mathrm{O}_{2}$ for the mentioned complexes is $\mathrm{Co}(\mathrm{II})>\mathrm{Fe}(\mathrm{II})>$ $\mathrm{Cu}$ (II) which is qualitatively followed by the theoretically determined reaction energies. The computations reveal that, in the case of $\mathrm{Ni}(\mathrm{II})$ and $\mathrm{Zn}(\mathrm{II})$, the lack of ability to transport dioxygen is due to inability to coordinate with DMSO and thus form the active complex. 


\section{Acknowledgements}

We would like to thanks to Facultad de Ciencias Químicas, Universidad Autónoma de Nuevo León for funding this project.

\section{Bibliography}

1. Hughes, M. N. The Inorganic Chemistry of Biological Processes, 2nd ed.; John Wiley \& Sons: London, 1981.

2. Kidd, R. D.; Baker, E. N.; Brittain, T. J. Biol. Inorg. Chem. 2002, 7, 23.

3. Stryer, L. Biochemistry, 4th ed.; Freeman: New York, 1995.

4. Collman, J. P. Inorg. Chem. 1997, 36, 5145.

5. Wallace, W. J.; Houtchens, R. A.; Maxwell, J. C.; Caughey, W. S.

J. Biol. Chem. 1982, 257, 4966.

6. Mauk, M. R.; Mauk, A. G. Biochemistry 1982, 21, 4730.

7. Matthews, C. K.; Van Holde, K. E. Biochemistry, Benjamin/Cumings: Redwood City, CA, 1990.

8. Stemp, E. D. A.; Hoffman, B. M. Biochemistry 1993, 32, 10848 .

9. Basolo, F.; Hoffman, B. M. Acc Chem Res 1975, 8, 384.

10. Cotton, F. A.; Wilkinson, G. Advanced Inorganic Chemistry, 4th ed.; Wiley Interscience: New York, 1990.

11. Wada, A.; Harata, M.; Hasegawa, K.; Jitsukawa, K.; Masuda, H.; Mukai, M.; Kitagawa, T.; Einaga, H. Angew. Chemie Int. Ed. 1998, 37, 798 .

12. Klinman, J. Chem Rev. 1996, 96, 2541.

13. Zipper, P.; Durchschlag, H. Physica A 2002, 314, 613.

14. Conzetti, A.; Fallab, S. Chimia 1973, 27, 435.

15. Pui, A. Croatica Chemica Acta 2002, 75, 165.

16. Eichhorn, E. J. Inorg. Chem. 1997, 36, 3307.

17. MOPAC2012, James J. P. Stewart, Stewart Computational Chemistry, Colorado Springs, CO, USA, http://OpenMOPAC.net (2012).

18. Jones, R. D.; Summerville, D. A.; Basolo, F. Chem. Rev. 1979, 79, 139. 